\title{
Banyumas Proper Names: Structure and Cultural Reflection
}

DOI:10.22515/jbs.v6i1.2441

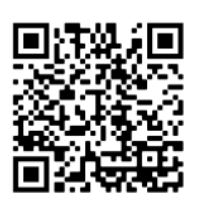

GITA ANGGRIA RESTICKA

gita.resticka@unsoed.ac.id

ERWITA NURDIYANTO

erwita.nurdiyanto@unsoed.ac.id

SRI NANI HARI YANTI

sri.yanti@unsoed.ac.id

Indonesian Literature Department, Universitas Jenderal Soedirman

Purwokerto, Indonesia

submitted: 11/5/2020 revised: 14/2/2021 accepted: 5/4/2021 published: 30/4/2021 pages: 13-22

ABSTRACT Proper name is a linguistic symbol that reflects people's perspectives and thoughts over something. This study aims to reveal current naming convention in Banyumas from linguistic perspective and to describe naming classification which covers list of proper names, their sociocultural background, the meanings, and the functions. This study used descriptive-qualitative method with snowball technique for the sampling. Banyumas proper names are dominated by the use of monomorphemic form. The languages used to give proper names come from local language, Bahasa Indonesia, as well as foreign languages. The naming structure covers first name, functioning as gender and birth order markers; middle name, containing ethnical or foreign element; and last name, containing family name. Naming reference mostly uses adjectives, famous figures' names, nature elements, flower names, puppet characters' names, and/or numbers and symbols. Prefix su- also characterizes some proper names in Banyumas. Cultural reflection from Banyumas proper names is that the proper names chosen by the name givers, mostly parents, resemble their hope and prayer for their children. Proper name as a part of culture and folklore becomes ethnical identity for the people themselves.

Keywords: proper name, Banyumas, culture

INTRODUCTION Naming process is one of earliest phases of a human life. The study of proper name is called as onomastics or onomatology. Onomastics covers naming system and structure, naming reference, and naming function (Anderson 2007). Naming system refers to the stems or themes that forms the name; combined themes called dithematic, and the uncombined one is called monothematic. Naming structure consists of first name, middle name, and last name (Van Langendonck 2007). Naming system in this study is included in semantics field (Chaer 2007). Although proper name is strongly related with its reference, it is often arbitrary and conventional. Thus, naming process can be done byadopting certain reference, shiftingthe meaning from its reference, or making a new one. Regardless all of this processing, naming process itself, naturally, is a form of prayer from the parents, as the name givers, towards their children.

Proper name is a social label for every individual (Bahiyah 2016) that shows their characteristics and at the same time indirectly reflects the society where they live. Banyumas proper names do not only show self identities and reflect the society, but also show their kinship. This research describes how Banyumas people generate proper names for their children and what factors affecting it. The current trend shows that Banyumas people tend to use foreign languages, or at least combine it with local language; famous figures' names, and nature and floral element; as well as refer to certain important events. This condition implies the shift of naming convention in Banyumas from traditional into modern one.

Proper name is a sociolinguistic marker, since it is affected by social, cultural, religious, and linguistic factors. Proper name is also a conventional 
label for social identification and communication (Widodo et al. 2010). Naming process is a psychological realization of the society to represent and brand themselves to the others (Widodo 2013). Naming process of each region has their own distinctive values and tradition, since it is affected by how the people see the sociocultural environment through the linguistic concept, especially in relation to the naming process.

In this modern time, some name processing still maintain the traditional value, but some also have adopted foreign elements in it, as in Robert Wicaksono, Patricia Agustin, Thomas Haryanto, Mohammad Lanang Dwi Setiawan, and Bagus Dwidjosoemarto. These examples show the distinctive features in naming process, like the family name, gender, and order of birth. It is in line with Irmayani (2015) 's research that in naming process, family name can be one of the consideration in generating a name, since it does not only show the identity, but also their rights and obligations within their family.

Besides used to address someone, as a label, proper name also represents the owner's image on the society (Kridalaksana 2005). From a linguistic perspective, proper name is a symbol which consists ofsignifier, the material aspect, and signified, the aspect of meaning. For example, in a boy name Aditya (sun), besides resembling a boy name, it also symbolizes the nature of the sun. Similarly, the name Legiyah resembles a female name from the gender marker yah, and it also shows the day she was born, that is Legi, name of a day in Javanese market days (pasaran). Wibowo (2001) also states that proper name, semantically, is related to variable reference and constant reference. In this case, proper name is related to symbolic meaning that is constructed by certain convention on certain culture. In order to get the desired name, naming process on a child have to undergo certain considerations in a hope that they will have a good life in the future. Naming process in Banyumas has experienced changes from time to time, and resulted in certain uses like to show kinship, order of birth, gender, and/or social status.

RESEARCH This research aims to describe the classification of naming structure and METHOD meaning of Banyumas people, whether there are certain distinctive features or systems in name processing or not. The result of this research also describes the sociocultural point of views, roles, and meaning of Banyumas people in terms of naming convention-diachronically. Thus, the relation between the names and the meanings can be identified which eventually can reveal the identity of Banyumas people.

This qualitative research identifies naming system classification through analyzing linguistic units of Banyumas proper names, since every culture has their own way to utilize language for establishing their society. This study is included as etnolinguistic research which aims to reveal Banyumas people's perspectives through analyzing linguistic elements on their proper names. The data were collected by getting random proper names of Banyumas people with emphasis on the variety of naming structure patterns as well as the underlying factors behind it, so the data could be varied and representative.

The data collection was conducted through observation, in-depth interview, field note, and literature review. The sampling used was snowballing technique, in which the subjects were chosen purposively from small network which then grew into the bigger ones. In other words, the researcher decided the first subject, and then the first subject decided the second subject for the researcher, and the second subject decided the third one, and so on. The 
researcher stopped when the data collected were enough and the answers given by the subjects became repetitively the same. The variety of data collection techniques used in this research were aimed to identify the sociocultural background that affected their proper names. The classification of the proper names are revealed through linguistic perspective. Meanwhile, the data analysis methods used in this research were identity method and distributional method. Data analysis was adjusted to the social context, since proper names are included as linguistic units which arise from the society itself. The result of the study is presented informally.

BANYUMAS Naming structure in Banyumas is varied, from using only mononym, which is PROPER NAMES now rarely to find, to the use of polynym, which is nowmore popular; like Mutia Maharani, Muhammad Bambang Purnama. This phenomena occured due to acculturation, and it happened convergently and divergently. Convergent process results in new names, while divergent process results in modified names that are adapted to certain Indonesian cultures.

Nowadays, the exposure of internet and television affects the way Banyumas people give names to the children, which implies that they try to put modernity for their proper names. Some of them, semantically, also still use proper names with literal meaning, like Bunga, Purnama, and Arif, though some also use proper names which are not taken from neither Bahasa dictionary nor Javanese one, like Jumirah and Wagiyem. This naming structure diversity actually shows the variety and continuous change of sociocultural factors as well.

The naming patterns of Banyumas proper names can be recognized from, at least, three aspects, namely language source, name structure, and linguistic unit. The source of language mostly used for giving names to children in Banyumas are English, Japanese, Arabic, Sanskrit, Ancient Javanese, and few other languages. Meanwhile, the name structure may consist of up to three parts, i.e.: first, middle, and last name. The first name is usually used to mark the sex or birth order of the name owner whereas the middle and last name, each generally represents Banyumas cultural element and family name. About the linguistic unit that constructs the name, it can be just a single word with several syllables or comprises two words or more. The former is exemplified by typical names, such as Dwi, Irma, Siswati, Rahmawati, Sugihastuti, and Kusumawardana, whereas the latter is shown by Doni Kurniawan, Santi Pujihastuti, Budi Permana Jati, and Dwi Trisna Indah Sari names.

Proper names with foreign adaptation, in which the spelling is Indonesianlike, such as Kristina, Akila, Zainudin are are written in foreign spellings into Cristina, Aqela, and Zenedin. This shows the current trend of name modification by substituting certain letters, like ' $k$ ' to ' $c$ ' in Cristina, ' $k$ ' to ' $q$ ' in Aqela, and 'ai' to ' $\mathrm{e}$ ' in Zenedin. The change of spelling affects much on the variety of proper names. The same case also happens within Bahasa Indonesia itself which has undergone three spelling system changes, from Van Ophuijsen's, Soewandi's, enhanced to current General Reference of Indonesian Spelling. Proper names that remain using old spelling system are, for example, Soemitro, Soetari Dardjowidjojo. In the old system, phoneme /u/ was written 'oe', phoneme /d $3 /$ was written ' $d j$ ', and phoneme $/ j$ / was written ' $j$ '.

Transliteration is also popular in Banyumas due to the exposure of internet and television. The higher the socioeconomic and educational background, the more interesting their proper names are; and usually they use ethnical 
and/or Islamic proper names. In the case of using foreign names, usually the spelling is kept and the structure uses Javanese system instead. In other words, Banyumas people do not really concern on the structure whether it is accordingly to the coresponding foreign language or not, as long as the names are meaningful.

The followings are some references used by Banyumas parents in giving names to their children.

1. noun phrase: Zahra Ulfa (fragrant and soft flower), Sabab Rizqi (she with abundant sustenance)

2. noun: Hidayah (guidance)

3. adjective: Sholeh, Sholehah (pious man/woman)

4. gender marker: Ratijan, Baridun, Saliman, Ngadimin, Warikam, Riskun (male); Saliyem, Juminten, Poniah, Setyaningrum, Darsih, Karsini (female)

5. birth order: $E k a$ (first), Dwi (second), Tri (third), Ragil (the youngest)

6. Javanese prefix su-: Suroso, Sutarno, Suroyo, Sunardi

7. ending with phoneme /o/: Wiyono, Haryono, Lasiyo, Siswoyo

8. ethnical characteristic: Teguh Triyono, Endang Sumarni, Agus Waluyo, Bambang Laksana

9. remarkable time/event: Mardika (independence day); Fitri Wulandari (Eid al Fitr), Wahyu Subhi (fajr), Lailatul Numah (night), Akbar Ramadhan (Ramadhan) Banjiriyah (flood)

10. Javanese market day (Pasaran)/month: Legiyah, Maniswati, Tugiyati (Sabtu legi); Parji (bulan Sapar tanggal siji)

11. month and year: Rahmad Januari (January), Eka Nawa Songo Songo (1999)

12. famous figure's name: Soekarno, Ahmad Gymnastiar

13. last prophet's name: Muhammad, Mochammad, Mukhammad

14. prophets' names combination: Muhammad llyas, Muhammad Zakaria

15. prophets' names and character combination: Muhammad Yunus Makarim, Muhammad llyas Azizi

16. dua and hope: Subagya (happy), Slamet (safe), Bejo (lucky)

17. nature element: Siti Nurmala Sari (earth); Tirto Ali (water) Agni Pratista (fire), Bayu Murdiyanto (wind)

18. floral element: Sekar Arum, Bunga Apriliani, Sukma Ayu

19. Wayang (puppet) character's name: Wisnu Afi, Bima Sakti Nugroho, Sinta Kumala Dewi, Srikandi.

Each name has their own distinctive features in terms of meaning or the underlying background. Thus, proper name can be called as a 'label' attached specifically for every individual, even if some individuals have the same names. Proper name is denotative, since it refers to the corresponding individual not the characters (Sumarsono 2014). However, proper name can be connotative as well in certain conditions if the locutor and illocutor share the same understanding.

Proper name can have biased or even double meaning. Meanwhile names like Muhammad or Sahetapi does not contain any information and is not family name as well. In other words, proper name can identify but cannot signify. In this case, the emphasis is on the identification rather than on signification.

Every language and culture have their own grammar, and in Banyumas, it is frequently found the use of prefix su-, like in the names Sutarjo and 
Sumiyati. The use of this grammatical feature is to differ proper name and noun. Based on criteria used to identify proper names, one dominant factor is the criterion functions as identification marker. Further, the fundamental difference between noun and proper name is in terms of function, in which noun is a meaningful unit, while proper name is an identification mark (Sumarsono 2014), that can be meaningful or not.

There is a reciprocal relationship between names and meanings, which means we can find the meaning of certain names-as if we take a look on a dictionary-or we can start with the meaning to find the name related to that meaning. Therefore, meanings behind the proper names can be analyzed from their cultural context or specific background of the name givers. Meanings behind proper names can symbolize the name givers' hope towards bountiful and successful life for their children as well as symbolize their ideology.

Naming system in Banyumas covers two ways to imbue meaning on the proper names. It can be morpheme to morpheme or word to word. Usually a mononym has a meaning on each morpheme, like Supriedisu (good), pria (man), and edi (handsome), and if combined becomes 'a good and handsome man'. Meanwhile, if the name is polynym, the meaning is on the level of word rather on the morpheme, like Akbar Munawir which means'great enlightener', since Akbar means 'great' and Munawir means 'enlightener'.

Current naming trend in Banyumas shows that they now tend to adopt, adapt, and combine foreign names into a lenghty name; instead of using simple naming system like what their ancestors did. Banyumas people now believe that the lenghtier the name the more hope and/or ideology they can put onto their children. Every individual has their rights to get special and meaningful name from the name giver(s), since proper name plays a significant role for every individual in society.

Cultural Koentjaraningrat (in Chaer \& Agustina 2004) states that language is a part of Reflection on the Naming Convention culture, though actually those two correspond to each other and cannot be separated from human's life (in Chaer 2007). Culture roles as a system that governs human's interaction within society with language as the means to enable the interaction (Paryono 2003, Priyadi 2008). Each culture has their own identity that distinguishes one culture to the others (Liliweri 2014). Banyumas also has its own cultural identity, like blakasuta, thokmelong accent, and bluntliness of speaking (Trianton 2016). Banyumas people are also open to change, which results in the diversity of proper names.

Proper name is an individual label that reflects their culture, language, and the society, since proper name itself is the product of people's ideology, system of thoughts, action, and interaction themselves (Chaer 2007). Proper name also reflects the name givers, mainly parents, hope over their children and perspective towards the world within its word choice, meaning, and naming structure. Furthermore, proper name can also reflect one's social status, religion, gender, ethnicity, and many others. According to Sudikan (in Sugiri 2003), name processing, which involves naming structure and imbuing meaning, is a part of culture and it can be further classified into certain convention. In relation to naming structure in Banyumas, it can be classified as follows.

Proper In this globalization era, where acculturation is expected in many places on Name as Cultural Identity this world, including in Banyumas, trend in name processing experiences shifting from the use of mononym, one word, to the use of polynym, two or 
more words, and from the use of local language to foreign one, whether it is adopted or adapted.

Name processing is also affected by folklore. Folklore itself is a tradition to pass down a legacy in the form of oral message, which usually contains historical and moral values, from generation to generation (Danandjaja 1994). In Banyumas, folklore affects the way they address someone, not directly on the proper names. It can be in the forms of vocatives and alias.In the former case, it is used to call someone with a sense of intimacy, for example the use of thole to address a boy, and nduk to address a girl. Besides giving a sense of intimacy, it also makes someone easier to call a boy or a girl even if they do not know their names. These vocatives usually are attached to someone since their childhood to adulthood. Meanwhile, in the latter case, it is usually called as paraban, that functions as a humour or to mock someone. The meaning behind the use of folklore as an underlying factor to address someone are as a form to show social status, belief, local wisdom, and hope.

Banyumas people's proper names are affected by the existing norms, traditional convention, myth, as well as Javanese culture and spirit. In other words, naming structure of Banyumas people is the manifestation of their interaction with the nature and the society, as well as their hope and prayer towards their children.

Naming Every culture has their own naming convention, though almost all of them, at Structure the end, just want to hope something good for their children through their Variation proper names. In addition to hope and prayer, for Banyumas people, proper name also roles as cultural identity. Cultural identity refers to individual awareness as a member of a society and the cultural values that govern the society in order to achieve social acceptance. In other words, by analyzing Banyumas people's proper names, their cultural identity can be understood.

There are several segmentation in Banyumas people' proper names. The emergence of western names likeThomas, Fransisca, and Bram connote that the owners of the names are modern, smart, and prestigious. There are also names that reflect certain community like Poniyem, Wage that are identical to Abangan people. Sastro, Ningrat, Kusuma are names that implies nobleness. Javanese names like Budi, Djoko, Retno reflect that the name givers try to show their pride towards Javanese ethnicity.Meanwhile, names such as Muhammad and Aminah are identical to santri (muslim scholar). This segmentation happens since people tend to show off their way of thinking, ideology, and desire. Moreover, there is also an urge from them to compete each other in showing something dignified. This segmentation also signs that proper names in Banyumas have undergone several changes, mostly on how they want to leave ethnical names and embrace more modern names. It is proven that the use of ethnical names are getting rarer from time to time. This change is mostly affected by the exposure of internet and television.

Proper There are several languages that are used in proper names in Banyumas: Jawa Names Kawi (ancient Javanese), modern Javanese, Bahasa Indonesia, Arabic, Japanese, Adopted and other foreign languages. Mostly, the reason why Banyumas people use from Foreign foreign language, either through adaptation or adoption, in their proper Language names is for the sake of prestige. The majority of Banyumas muslims have Arabic names, for example. In another case, some people even change their names after they conducted hajj. However, although they use foreign names 
as their proper names, it does not necessarily mean they are grammatically correct.

In using foreign language, some Banyumas people do not only use one language, but they also mix and match two or more languages into one as long as the result has a good meaning. They even try to combine foreign languages with Javanese, since they still want to keep the sense of ethnicity in their proper names, for example Siti Aisyah and Siti Anastasia. Both the names have Javanese name Siti, but the former has Arabic name Aisyah and the latter has western name Anastasia.

Naming system in Banyumas also shows parents' desire to inherit Arabic names to their children whether combined with other languages or not since they want their children's names to sound nice and Islamic. Besides, they also want the names to be lenghty and uncommon, so other children cannot have the same name as theirs. For example, there are names that contain the God's names, or is called as Asmaul Husna, like the name Al Malik Nuryanto. Besides combining two languages, some of them also use pure Arabic in their proper names like the name Arum Masyitoh.

In general, factors that underline the use of foreign languages are that the parents want meaningful and modern proper names for their children, prestige of making good names, and a competition with the other parents. Moreover, it is not dubious that globalization, which makes everything borderless and connected, is the major factor that affects it. Internally, there are also some lacks within Banyumas people that foreign languages can dominate their naming system, such weak cultural foundation, no stricted norm to prevent, high social competitiveness, wide mobility, and easy-to-use technology. Thus, it causes the marginalization and the abandonment of using local names, though fortunately some people are still considerate about their culture and tradition by still using Javanese names or, at least, making combined names between local language with the foreign one.

Psychologically, nowadays, some young people are ashamed with their own names and feel more proud with modern names, so they try to change their own names following the current trend. For example, there is a woman whose name is /chi, but whe she left the village and moved to the town she changed her name into /cha. In some cases, they do not change how their names sound, rather they change the way their names are spelled like Andrew, Michael, Misca, and the others. This phenomenon is called as internationalization process, since many Banyumas people begin to leave their naming tradition. In line with these case, Sutanto (2002) states that the notion of 'international name' is one of global society characteristics and the reflection of people's perspectives towards modernity and globalization.

Proper Name processing takes a lot of considerations towards its meaning, which Names as a makes people believe that name can determine someone's fate. Therefore, Sociocultural inappropriate names can bring bad luck to them. However, psychologically, Identity name is pride which means good names can bring confidence to the owners. Proper name also functions as social identity to the owner by which people label them. In socio-cultural context within Javanese society, the way we address someone's proper names represents our politeness, since proper names can be addressed in some ways to imply mockery, salutation, complaint, intimacy, and the other intentions. 
Proper Proper name can be affected by the name giver's background. The idea can Names as a come out from many references depending on the name giver, it can be Reference to referred from foreign language, family name, and/or certain important event. Certain Event In the case for remarkable time/event, some parents as the name givers relate their children's dates of birth to the event correspond to them; so it can be easier for them to commemorate the birth date. They try to make the commemoration of the birth date easier, since they want to always be grateful to the God for the children given to them. There is also a case where a child's name is the same with her mother, since the name giver wants her to always remember her mother who had died in the struggle to give a birth.

Proper Proper name contains linguistic and cultural elements. In terms of linguistic Names as a

Part of Tradition aspect, proper name is a linguistic unit in the form of a word or phrase which contains certain concept, while in terms of cultural aspect, it refers to the choice of those proper names themselves. The use of language in Banyumas affects the way they give proper names to their children and since language is a part of culture, any concept of name processing is bound by the culture. In other words, naming process reflects the culture itself in many ways like its belief, perspective, politeness, and the others.

In general, proper names in Banyumas have certain characteristics based on the parents' social class and cultural orientation, for example if the parents are farmers, they will not give noble names to their children because they are afraid if this can bring misfortune to the their children instead. There is also a term kabotan jeneng (burdened by the name) which makes lower social people afraid to give noble names to their children because they believe this brings misfortune or unhealthy body to their children-even this can bring death to the children. However, if this actually happens, they can change their children names to cleanse this misfortune (Herusatoto 2008).

There is also a ritual in accordance to the process of giving name in Banyumas, it is called as slametan (celebrating safety). Slametan is a ritual of thanksgiving to the God and as a form of prayer for the children. There is also a tradition in Banyumas to give family name within the children names, it can be father's name, grand father's, grand grand father's, and higher. This patronymic tradition hopefully can honor the family in every achievement the children will get in the future. In Banyumas, there are several variations in giving family name to the children as can be seen in Table.

Table: Patronymic Naming

\begin{tabular}{lll}
\hline \multicolumn{1}{c}{ Base } & \multicolumn{1}{c}{ Parent Name } & \multicolumn{1}{c}{ Child Name } \\
\hline Last name & Heri Pratomo & Anistya Wulandari Pratomo \\
First name & Bramayuda & Bram Nugraha \\
First syllable & Djohar & Jonathan \\
Last syllable & Darlim & LimKusnandar \\
Root & Sugito & Gito Waluyo \\
\hline
\end{tabular}

Proper Related to the people's belief, there is naming process in changing one's Name name. In chosing the proper name, careful process is involved. It is carefully Changes done as there are some reasons why someone changes his or her name and one of the reason is to create positive image. Another reason is that, sometimes, there is a mismatch between the name and its owner that may cause bad effects. For famous celebrities or artists, comercially, the meaning of 
their name is not the main consideration. Instead, they choose more impressive proper names that will make them more famous than what they are before. The underlying reason why someone change his or her name is cultural selection, customs, convention, social contract, and myth. Name is a symbol for the owner. In Banyumas, one may have different names for his or her different phases of life. There is a unique tradition in giving one a name which is the changing from the real name into new name he or she gets after marriage. This name is known as jeneng tuwa (elderly name). Besides, the name embbeding becomes the symbol of lineage.

After the marriage, in giving jeneng tuwa, there is also a certain tradition. This tradition, known as slametan, is similar to what the people do when they give their children names soon after they was born. In slametan, there are particular foods made which are ketan and bubur merah putih. The two particular foods are expected to symbolize the emotional bond and the unification of the bride's and groom's name so that one new name is given for them both. It does not mean that the bride and groom do not still use their birth name, jeneng tuwa like Parno Waluyo, Ahmad Sukarto, Slamet Karyono is just used to symbolize their new marriage status although some people feel more comfortable with their jeneng tuwa so that they do not use their birth names anymore. Some people still preserve this tradition so that it can be passed on over generations.

CONCLUSION Naming structure in Banyumas experiences changes from time to time. Naming structure patterns in Banyumas cover the use of noun phrase, adjective, noun, gender and birth order marker, important event reference, prefix su-, ending with phoneme $/ \mathrm{\rho} /$, ethnical, nature, and floral elements; wayang character's name, pasaran, prophet's name, famous figure's name, as well as celestial element. Meanwhile, the notion of cultural reflection of Banyumas proper names covers name as a sociocultural identity, variety of proper name structures, foreign adaptation and adoption in proper names, proper names as reference to certain remarkable time/events, proper names as part of tradition, and the change of proper names.

Anderson, James M. 2007. The Grammar of Names. Oxford: Oxford University Press. https://doi.org/10.1093/acprof:oso/9780199297412.001.0001

Bahiyah, Laila Nurul. 2016. Struktur Nama Serapan dari Bahasa Arab pada Masyarakat Jawa di Kabupaten Rembang Jawa Tengah: Kajian Etnolinguistik (Skripsi). Surabaya Airlangga University. http://repository.unair.ac.id/56092/

Chaer, Abdul. 2007. Kajian Bahasa: Struktur Internal, Pemakaian, dan Pemelajaran. Jakarta: Rineka Cipta

Chaer, Abdul \& Leonie Agustina. 2004. Sosiolinguistik: Perkenalan Awal. Jakarta: Rineka Cipta

Danandjaja, James. 1994. Folklor Indonesia: IImu Gosip, Dongeng, dan lain lain. Jakarta: Grafiti Pers

Herusatoto, Budiono. 2008. Banyumas: Sejarah, Budaya, Bahasa, dan Watak. Yogyakarta: LKiS Pelangi Aksara

Irmayani. 2015. "Nama Marga Etnik Tionghoa sebagai Penanda Penetapan Keturunan dalam Sistem Kekerabatan Etnik Tionghoa di Pontianak". Metalingua: Jurnal Penelitian Bahasa 13 (1): 29-37. https://doi.org/10.26499/metalingua.v13i1.52

Kridalaksana, Harimurti. 2005. Kamus Linguistik. Jakarta: Gramedia Pustaka Utama

Liliweri, Alo. 2014. Pengantar Studi Kebudayaan. Yogyakarta: Nusa Media

Paryono, Yani. 2003. "Keunikan Bahasa Jawa Dialek Banyumas sebagai Cerminan Identitas Masyarakat Banyumas". Kongres Bahasa Jawa V. Surabaya. https://ki- 
demang.com/kbj5/index.php/makalah-pengombyong/1203-21-keunikan-bahasajawa-dialek-banyumas-sebagai-cerminan-identitas-masyarakat-banyumas /

Priyadi, Sugeng. 2008. "Orientasi Nilai Budaya Banyumas: Antara Masyarakat Tradisional dan Modern". Humaniora 20 (2): 158-167. https://doi.org/10.22146/jh.933

Sugiri, Eddy. 2003. "Perspektif Budaya Perubahan Nama Diri bagi WNI Keturunan Tionghoa di Wilayah Pemerintah Kota Surabaya". Bahasa dan Seni 31 (1): 54-68

Sumarsono. 2014. Sosiolinguistik. Yogyakarta: Pustaka Pelajar

Sutanto, Irzanti. 2002. "Ganti Nama di Kalangan Keturunan Tionghoa Peraturan dan Kebebasan". Wacana 4(2):140-149. https://doi.org/10.17510/wjhi.v4i2.332

Trianton, Teguh. 2016. Bahasa sebagai Identitas dan Perlawanan Kultural Masyarakat Banyumas Pascakolonial [Preprint]. INA-Rxiv. https://doi.org/10.31227/osf.io/h8rsy

Van Langendonck, Willy. 2007. Theory and Typology of Proper Names. Berlin and New York: Mouton de Gruyter. https://doi.org/10.1515/LING.2009.042

Wibowo, Ridha Mashudi. 2001. "Nama Diri Ełnik Jawa". Humaniora 13 (1), 45-55. https://doi.org/10.22146/jh.v13i1.710

Widodo, Sahid Teguh. 2013. "Konstruksi Nama Orang Jawa Studi Kasus Nama-nama Modern di Surakarta". Humaniora 25(1), 82-91. https://doi.org/10.22146/jh.v25i1.1815

Widodo, Sahid Teguh, Nuraini Yussof \& Hisham Dzakiria. 2010. "Nama Orang Jawa: Kepelbagaian Unsur dan Maknanya". Sari: International Journal of the World and Civilisation 28 (2): 259-277

\section{ARTICLE CITATION IN THE CHICAGO MANUAL OF STYLE 16}

\section{In-text Citation}

Resticka, Nurdiyanto, and Yanti $(2021,17) \ldots .$.

..... (Resticka, Nurdiyanto, and Yanti 2021, 17)

\section{Reference List Entry}

Resticka, Gita Anggria, Erwita Nurdiyanto, and Sri Nani Hari Yanti. 2021. "Banyumas Proper Names: Structure and Cultural Reflection". Leksema: Jurnal Bahasa dan Sastra 6 (1): 13-22. https://doi.org/10.22515/ljbs.v6i1.2441.

Copyright @ 2021 Leksema: Jurnal Bahasa dan Sastra 